\title{
Cytokine Regulation of Immunoglobulin Secretion by Neonatal Lymphocytes
}

Judy B. Splawski* and Peter E. Lipsky*

Departments of Pediatrics* and Internal Medicine, ${ }^{\ddagger}$ and Harold C. Simmons Arthritis Research Center, ${ }^{\ddagger}$

University of Texas Southwestern Medical Center, Dallas, Texas 75235

\begin{abstract}
In contrast to adult lymphocytes, neonatal lymphocytes secrete minimal amounts of $\mathrm{Ig}$ in response to stimulation with immobilized MAb to CD3. This deficiency could be overcome by the addition of supplemental IL-2, IL-4, or IL-6, resulting in the secretion of all Ig isotypes. There were no major differences in the distribution of $\mathrm{Ig}$ isotypes secreted in response to the cytokines alone or in combination. The Ig secreted in response to IL-4 or IL-6 was inhibited by MAb to CD25, suggesting that the effects of IL-4 and IL-6 were dependent on IL-2. Stimulation of neonatal lymphocytes with anti-CD3 was sufficient to induce expression of $\mathrm{IL-2}$ receptors (CD25) on both T and B cells. IL-4 exerted direct effects on neonatal T cells by increasing IL-2 production and promoting IL-6 production by antiCD3-stimulated neonatal lymphocytes. Antibody to IL-4 or IL6 did not inhibit Ig secretion in response to IL-2 and antibody to IL-6 did not consistently inhibit Ig secretion in response to IL-4. Finally, in the presence of cyclosporin, anti-CD3-stimulated neonatal lymphocytes secreted Ig only with the combination of IL-2 and IL-4. These results have delineated unique, but not Ig isotype-specific, effects of cytokines in supporting Ig secretion by anti-CD3-stimulated neonatal lymphocytes. Deficient production of these cytokines is likely to contribute to the decreased capacity of neonatal lymphocytes to generate an Ig response. (J. Clin. Invest. 1991. 88:967-977.) Key words: interleukin 4 - interleukin $2 \cdot$ interleukin $6 \cdot \mathrm{CD} 3$ - cyclosporin
\end{abstract}

\section{Introduction}

Neonates are deficient in their ability to produce $\operatorname{Ig}(1)$. In vitro studies have demonstrated deficiencies in both $\mathrm{T}$ and $\mathrm{B}$ cell function $(2,3)$. Previous studies employing immobilized antiCD3 MAb, a powerful stimulus for Ig secretion by adult lymphocytes, demonstrated that neonatal $B$ and $T$ cells were unable to produce Ig of any isotype (4). Neonatal lymphocytes could be induced to secrete Ig in response to anti-CD3 stimulation if exogenous cytokines in the form of supernatants from mitogen-activated adult $T$ cells were supplied. These results suggested that either cytokine production by neonatal lymphocytes is functionally deficient or that neonatal lymphocytes are

Address reprint requests to Dr. Lipsky, Department of Internal Medicine, University of Texas Southwestern Medical Center, 5323 Harry Hines Blvd., Dallas, TX 75235-8884. 1991.

Received for publication 13 March 1991 and in revised form 20 May

1. Abbreviation used in this paper: $\mathrm{PE}$, phycoerythrin.

J. Clin. Invest.

(c) The American Society for Clinical Investigation, Inc. $0021-9738 / 91 / 09 / 0967 / 11 \quad \$ 2.00$

Volume 88, September 1991, 967-977 less responsive to cytokines. The current studies were designed to examine these issues and focused on the roles of IL-2, IL-4, IL- 6 , and IFN- $\gamma$ in the regulation of the capacity of neonatal lymphocytes to produce Ig.

IL-4 has important regulatory effects on both $\mathrm{T}$ and $\mathrm{B}$ cell differentiation and may be important in the regulation of $\mathrm{Ig}$ isotype switch (5-9). Moreover, naive T cells are deficient in their ability to produce IL-4 (10-13). IFN- $\gamma$ is also reported to play an important regulatory role in Ig isotype switching (14, 15) and production of this cytokine by naive $T$ cells is also reported to be deficient $(16,17)$. IL-6 promotes $T$ cell activation and $\mathrm{Ig}$ production by $\mathrm{B}$ cells (18-20). However, the importance of this cytokine in the enhancement of $\mathrm{Ig}$ production by naive $B$ and $T$ cells has not been well characterized. Therefore, the ability of these cytokines to promote Ig secretion and to influence the Ig isotypes secreted by anti-CD3-stimulated neonatal lymphocytes was investigated.

The results demonstrate that IL-2 is essential for the differentiation of neonatal B cells but that IL-4 and IL-6 also promote Ig secretion by neonatal $B$ and $T$ cells. The complex interplay of these cytokines appears to determine the magnitude of the antibody response of anti-CD3-activated neonatal lymphocytes. Although minor differences in the Ig heavy-chain isotypes secreted in response to the various cytokines were noted, no cytokine specific effects on the pattern of secreted Ig isotypes were demonstrated.

\section{Methods}

Cell preparation. Peripheral blood mononuclear cells (PBMC) were isolated from heparinized venous blood of healthy adult volunteers by centrifugation over sodium diatrizoate/ficoll gradients (Pharmacia, Inc., Piscataway, NJ) as described (21). Cord blood of healthy newborns was collected at the time of delivery in Alsevier's solution and mononuclear cells were prepared as above.

Culture medium. All cultures were carried out in medium RPMI 1640 (Gibco Laboratories, Grand Island, NY), supplemented with penicillin $\mathrm{G}(200 \mathrm{U} / \mathrm{ml})$, gentamicin $(10 \mu \mathrm{g} / \mathrm{ml}$, Sigma Chemical Co., St. Louis, MO), L-glutamine $(0.3 \mathrm{mg} / \mathrm{ml})$, and $10 \%$ fetal bovine serum (FBS, Microbiological Associates, Walkersville, MD).

Reagents. Recombinant purified IL-2 was obtained from the Biological Response Modifiers Program at the National Institutes of Health. Recombinant human IL-4 was obtained from Research and Diagnostic Systems, Minneapolis, MN and was used at a final concentration of 2 $\mathrm{ng} / \mathrm{ml}(100 \mathrm{U} / \mathrm{ml})$. The $\mathrm{ED}_{\mathrm{s0}}$ of this material was $0.3-0.9 \mathrm{ng} / \mathrm{ml}$ determined by $\left[{ }^{3} \mathrm{H}\right]$ thymidine incorporation of human peripheral blood $\mathrm{T}$ lymphocytes. Human purified recombinant IL-6 was the kind gift of Dr. T. Hirano and Dr. T. Kishimoto $(22,23)$. Cyclosporin A (Sandoz Pharmaceutical Co., East Hanover, NJ) was diluted in dimethyl sulfoxide (DMSO) and used at a final concentration of $100 \mathrm{ng} / \mathrm{ml}$. IFN- $\gamma$ was obtained from Amgen Biologicals, Thousand Oaks, CA, and used at a concentration of $100 \mathrm{U} / \mathrm{ml}$ ).

Antibodies. 64.1 is an IgG2a MAb directed at the CD3 molecular complex on mature $T$ cells (24). 64.1 was purified over a column of Sepharose 4B coupled with staphylococcal protein A. Anti-Tac, a MAb directed at the p55 component of the IL-2 receptor (CD25), was 
generously provided by Dr. T. Waldmann, National Cancer Institute, National Institutes of Health (25). Anti-CD25 conjugated to phycoerythrin (PE) and anti-CD20-fluorescein isothiocyanate (FITC) were purchased from Becton, Dickinson \& Co., San Jose, CA. 2H4 (Coulter Immunology, Hialeah, FL) is an IgG1 antibody to the CD45RA molecule (26). Rabbit antibody to human IL-6 was obtained from Amgen Biologicals and diluted $1: 150$ to neutralize $40 \mathrm{ng} / \mathrm{ml}$ of IL-6. 8F-12, an IgG1, MAb to human IL-4 was the kind gift of Dr. C. H. Heusser, Basel, Switzerland (10).

Cell separation. PBMC from adult peripheral blood and cord blood were depleted of monocytes and natural killer (NK) cells by incubation with $5 \mathrm{mM}$ L-leucine methyl ester (Sigma Chemical Co.) in serum-free medium $(27,28)$. After washing, B cells were depleted of $T$ cells by two cycles of rosetting with neuraminidase-treated sheep red blood cells (29). Adult B cells prepared in this fashion are $>90 \%$ CD20 positive, as has been previously established (30). Cord blood B cells were 70-75\% CD20 positive, and $75-90 \%$ CD19 positive. Approximately $85-90 \%$ of both the cord and adult CD20-positive cells stained positively for IgD. The B cell preparations contained $<1 \%$ CD3-positive cells. Sedimented rosette-forming cells from the first centrifugation were treated with isotonic $\mathrm{NH}_{4} \mathrm{Cl}$ to lyse the sheep $\mathrm{RBC}$. Adult and cord blood $\mathrm{T}$ cell populations were $>95 \% \mathrm{CD3}^{+}$. $\mathrm{T}$ cells were subjected to $2,000 \mathrm{rad}$ of $\gamma$-irradiation before culture.

Culture conditions. 64.1 was diluted in $0.05 \mathrm{M}$ Tris, $\mathrm{pH} 9.5$, the concentration was adjusted to $4 \mu \mathrm{g} / \mathrm{ml}$, and $50 \mu \mathrm{l}$ were placed in each of the wells of 96-well microtiter plates (Costar, Cambridge, MA) and incubated at room temperature for 1-5 h. Afterward, the wells were washed twice with medium to remove nonadherent MAb before the addition of cells (31). Routine cultures were carried out in triplicate in a total volume of $200 \mu \mathrm{l}$ per well. T cells were added at a density of 1.0 $\times 10^{5}$ per well and B cells were added at $2.5 \times 10^{4}$ per well unless indicated otherwise. The cultures were incubated at $37^{\circ} \mathrm{C}$ in a humidified atmosphere of $5 \% \mathrm{CO}_{2}$ and $95 \%$ air. Supernatants for quantitation of Ig secretion were harvested at varying time points as indicated.

Measurement of $\mathrm{Ig}$ secretion. Ig in the culture supernatants was quantitated utilizing isotype-specific ELISAs as previously described $(7,32)$. The sensitivities of the specific assays are as follows: IgM, 24 $\mathrm{ng} / \mathrm{ml}$; IgG and IgA, $12 \mathrm{ng} / \mathrm{ml}$. IgG subclass production was determined utilizing purified mouse IgG MAb to human IgG subclasses, (IgG1-JDC 1, IgG4-JDC 14, Southern Biotechnology Associates, Birmingham, AL; IgG2-HP6014, IgG3-HP6047, American Type Culture Collection, Rockville, MD) bound to microtiter plates coated with goat anti-mouse IgG Fc fragment (Cappel Laboratories, Cooper Biochemical, Malvern, PA) as previously described $(7,33)$. Bound IgG was detected with peroxidase-conjugated affinity-purified goat anti-human IgG (Tago, Inc., Burlingame, CA) and compared to serial dilutions of purified myeloma IgG subclass standards, a kind gift of Dr. Hans Spiegelberg, La Jolla, CA. The sensitivity of the IgG subclass assays is 12 $\mathrm{ng} / \mathrm{ml}$.
IL-2 assay. Supernatants to be assayed for IL-2 production were obtained after incubation of neonatal T cells $\left(1.0 \times 10^{5}\right.$ per well $)$ for 72 $\mathrm{h}$ with immobilized anti-CD3 in the presence of $5 \mu \mathrm{g} / \mathrm{ml}$ anti-CD25. Supernatants were filtered and frozen before assay. IL-2 production was determined by incubation of CTLL cells $\left(5 \times 10^{3}\right.$ cells per well) suspended in $100 \mu \mathrm{l}$ of medium containing $10 \%$ FBS with $100 \mu \mathrm{l}$ of the culture supernatant to be assayed or various concentrations of recombinant IL-2 diluted in culture medium. $\left[{ }^{3} \mathrm{H}\right]$ Thymidine incorporation was assessed after $28 \mathrm{~h}$ with $\left[{ }^{3} \mathrm{H}\right]$ thymidine present for the last $8 \mathrm{~h}$. IL-2 production was determined by comparing CTLL $\left[{ }^{3} \mathrm{H}\right]$ thymidine incorporation supported by supernatants with that supported by known concentrations of recombinant IL-2 (34). This assay detects IL-2 but not other cytokines.

IL-6 assay. IL-6 in the culture supernatants was quantitated utilizing an immunoassay specific for human IL-6 (Amgen Diagnostics, Thousand Oaks, CA) the sensitivity of the assay is $10 \mathrm{pg} / \mathrm{ml}$. This assay is specific for IL-6.

Immunofluorescence analysis. B cells $\left(1 \times 10^{6}\right)$ and $\mathrm{T}$ cells $\left(1 \times 10^{6}\right)$ were incubated with immobilized anti-CD3 in $1 \mathrm{ml}$ of medium with or without cytokines in 16-mm flat-bottomed polystyrene plates (Corning Glass, Inc., Corning, NY). Cells were harvested and stained simultaneously with anti-CD20-FITC to distinguish B cell populations and anti-CD25-PE and fixed with $1 \%$ paraformaldehyde. Immunofluorescence was analyzed with the fluorescence-activated cell sorter. Expression of CD45RA was investigated after incubation of neonatal T cells $\left(2 \times 10^{6}\right)$ with immobilized anti-CD3 in $16-\mathrm{mm}$ wells with or without cytokines. Cells were harvested after varied periods of incubation, stained with anti-CD45RA or control antibody, fixed, and analyzed with the fluorescence-activated cell sorter (Becton, Dickinson \& Co., Mountain View, CA).

Statistics. The Wilcoxon signed rank test or paired $t$ test was utilized to determine the significance of differences between paired samples.

\section{Results}

Ig secretion by anti-CD3-stimulated adult lymphocytes. The Ig secreted by anti-CD3-stimulated adult lymphocytes is detailed in Table I. Anti-CD3 stimulation alone results in the secretion of large amounts of IgM, IgG1, and IgA. However, production of all Ig isotypes including substantial amounts of IgE were also observed. Supplementation of these cultures with IL-2, IL-4, or IL-6 had no major effect on the amounts of the various Ig isotypes secreted, except for IgE which was increased by the addition of IL-2 or IL-4. Addition of combinations of the cytokines had no additional effects beyond that noted with the addition of IL-2 or IL-4 alone (data not shown). These results

Table I. Immunoglobulin Secretion by Anti-CD3-stimulated Adult Lymphocytes

\begin{tabular}{lcrccccc}
\hline & \multicolumn{7}{c}{ Ig isotype secreted } \\
\cline { 2 - 8 } Addition & \multicolumn{1}{c}{ IgM } & \multicolumn{1}{c}{ IgG1 } & IgG2 & IgG3 & IgG4 & IgA & IgE \\
\hline & & & $\mu g / m l$ & & & \\
Nil & $17.97 \pm 1.64$ & $12.59 \pm 2.54$ & $0.73 \pm 0.25$ & $1.52 \pm 0.38$ & $0.24 \pm 0.12$ & $16.79 \pm 2.03$ & $0.038 \pm 0.014$ \\
IL-2 & $16.35 \pm 0.90$ & $9.55 \pm 1.69$ & $0.65 \pm 0.26$ & $1.11 \pm 0.22$ & $0.17 \pm 0.06$ & $13.09 \pm 3.14$ & $0.090 \pm 0.036^{*}$ \\
IL-4 & $16.05 \pm 2.28$ & $11.41 \pm 2.51$ & $0.57 \pm 0.19$ & $1.58 \pm 0.41$ & $0.20 \pm 0.05$ & $15.02 \pm 2.30$ & $0.097 \pm 0.025^{*}$ \\
IL-6 & $17.97 \pm 2.62$ & $14.14 \pm 2.78$ & $1.34 \pm 0.71$ & $2.29 \pm 0.87$ & $0.36 \pm 0.24$ & $17.51 \pm 1.80$ & $0.056 \pm 0.015$ \\
& & & & & & & \\
\end{tabular}

Adult B cells $\left(1.0-2.5 \times 10^{4}\right.$ per well) and T cells $\left(1.0 \times 10^{5}\right.$ per well) were incubated with immobilized anti-CD3 with or without supplemental IL-2 $(50 \mathrm{U} / \mathrm{ml})$, IL-4 $(100 \mathrm{U} / \mathrm{ml})$, or IL-6 $(10 \mathrm{U} / \mathrm{ml})$. Supernatants were harvested for quantitation of Ig secreted on day 12 or 15 . The results are expressed as the mean \pm SEM for six experiments. * Enhancement of Ig secretion above that secreted in the absence of cytokines $(P \leq 0.05$, Wilcoxon signed rank). 


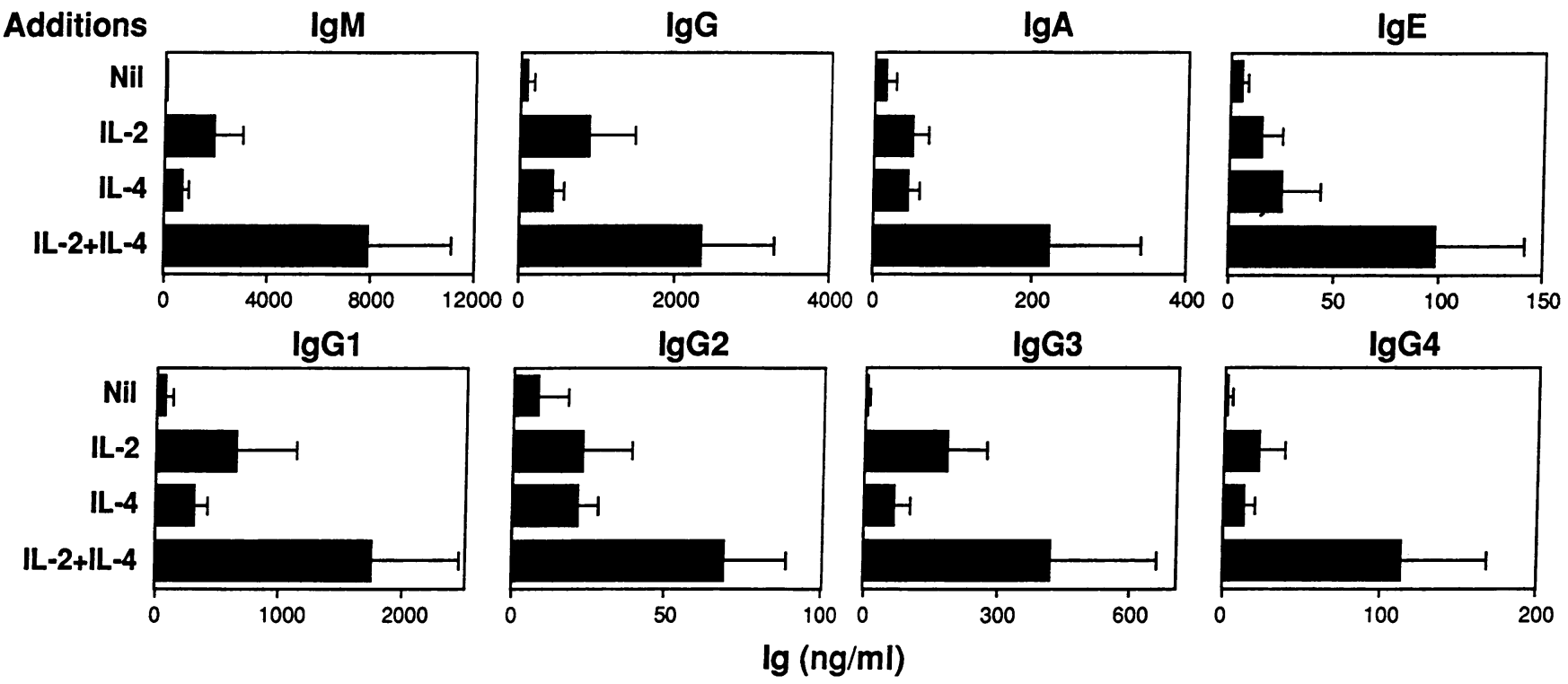

Figure 1. Ig secretion by anti-CD3-stimulated neonatal T and B cells cultured with IL-2 and IL-4. Cord B cells (5-25 $\times 10^{4}$ per well) were incubated with cord T cells $\left(1.0 \times 10^{5}\right.$ per well) in the presence of immobilized anti-CD3 with or without IL-2 $(50 \mathrm{U} / \mathrm{ml})$ or IL-4 (100 U/ml, 2 $\mathrm{ng} / \mathrm{ml}$ ). Supernatants were harvested at multiple time points from day 5 to day 20 for analysis of Ig secretion. The results presented are the means \pm SEM of the maximal Ig secreted for each isotype for six experiments. IL-2 enhanced the secretion of all Ig isotypes except IgG1; IL-4 increased all but IgG1, IgG2, IgA; and the combination of IL-2 and IL-4, enhanced all Ig isotypes $(P<0.05)$. No differences were noted between the patterns of Ig isotypes secreted in the presence of IL-2 or IL-4 alone. The combination of IL- 2 and IL- 4 enhanced the secretion of all Ig isotypes above that obtained with IL-2 alone except for IgG3 $(P<0.05)$.

suggest that anti-CD3 stimulation alone was sufficient to stimulate large amounts of Ig secretion by the adult lymphocytes and that with the exception of IgE supplemental cytokines were not required.

Induction of Ig secretion by anti-CD3-stimulated neonatal $B$ and $T$ cells with supplemental cytokines. We previously reported that anti-CD3 stimulation was not sufficient to induce Ig secretion by neonatal $B$ and $T$ cells. Therefore, the initial experiments examined the influence of various cytokines on Ig production by anti-CD3-stimulated neonatal lymphocytes. For these experiments Ig secretion was assayed at multiple time points over 5-20 d and the maximal levels of the various Ig isotypes determined. In the absence of supplemental cytokines, anti-CD3-stimulated neonatal lymphocytes secreted minimal Ig (Fig. 1). Addition of supplemental IL-2 or IL-4 resulted in the secretion of all Ig isotypes. Comparison of the Ig isotypes secreted in response to IL-2 and IL-4 demonstrated no consistent differences in the isotype of Ig secreted although IL-2 supported more IgM and IgG3 secretion than IL-4. The combination of IL-2 and IL-4 markedly increased the secretion of all Ig isotypes above that induced by either cytokine alone. In each experiment shown in Fig. 1, detailed kinetics of Ig production

Table II. Interferon- $\gamma$ Does Not Inhibit the Effect of IL-4 on Anti-CD3-stimulated Ig Secretion by Neonatal Lymphocytes

\begin{tabular}{lcccccccc}
\hline & & \multicolumn{7}{c}{ Ig isotype secreted } \\
\cline { 3 - 8 } Addition & IFN- $\gamma$ & IgM & IgG1 & IgG2 & IgG3 & IgG4 & IgA \\
\hline & & & & $\mu g / m l$ & IgE \\
Nil & - & $237 \pm 139$ & $71 \pm 39$ & $0 \pm 0$ & $11 \pm 7$ & $0 \pm 0$ & $0 \pm 0$ & $0 \pm 0$ \\
& + & $494 \pm 239$ & $90 \pm 77$ & $9 \pm 9$ & $17 \pm 14$ & $0 \pm 0$ & $5 \pm 5$ & $0 \pm 0$ \\
IL-2 & - & $3,505 \pm 2,006$ & $720 \pm 447$ & $33 \pm 23$ & $244 \pm 157$ & $34 \pm 23$ & $31 \pm 14$ & $12 \pm 6$ \\
& + & $6,245 \pm 3,854$ & $991 \pm 790$ & $32 \pm 21$ & $262 \pm 223$ & $19 \pm 12$ & $32 \pm 22$ & $19 \pm 13$ \\
IL-4 & - & $1,152 \pm 564$ & $287 \pm 148$ & $35 \pm 21$ & $56 \pm 38$ & $49 \pm 45$ & $23 \pm 19$ & $17 \pm 11$ \\
& + & $2,427 \pm 1,082^{*}$ & $338 \pm 168$ & $48 \pm 28$ & $73 \pm 41$ & $52 \pm 36$ & $32 \pm 20^{*}$ & $24 \pm 13^{*}$ \\
IL-2 + IL-4 & - & $9,425 \pm 2,783$ & $1,141 \pm 529$ & $92 \pm 45$ & $148 \pm 64$ & $151 \pm 75$ & $70 \pm 29$ & $59 \pm 17$ \\
& + & $11,848 \pm 3,112^{*}$ & $860 \pm 437$ & $76 \pm 34$ & $159 \pm 78$ & $91 \pm 45$ & $71 \pm 34$ & $56 \pm 18$
\end{tabular}

Neonatal B cells $\left(2.5 \times 10^{4}\right.$ per well $)$ were incubated with irradiated neonatal T cells $\left(1.0 \times 10^{5}\right.$ per well $)$ and immobilized anti-CD3 in the presence or absence of supplemental cytokines (IL-2, $50 \mathrm{U} / \mathrm{ml}$; IL-4, $100 \mathrm{U} / \mathrm{ml}$; or IFN- $\gamma 100 \mathrm{U} / \mathrm{ml}$ ). Supernatants were harvested for quantitation of Ig secreted on day 15 . The results are expressed as the mean \pm SEM for five experiments. ${ }^{*}$ Enhanced Ig secretion in the presence of IFN- $\gamma(P \leq 0.05$; paired $t$ test $)$. 
Additions

IgM

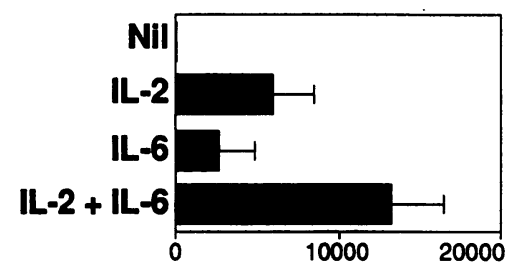

lgG1

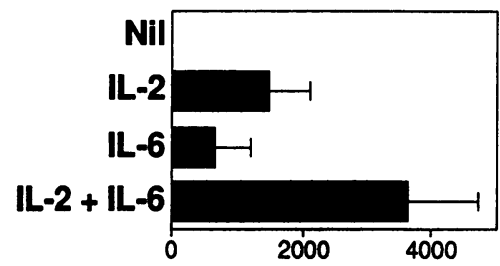

$\lg G$

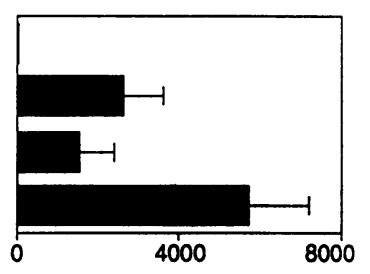

IgG2

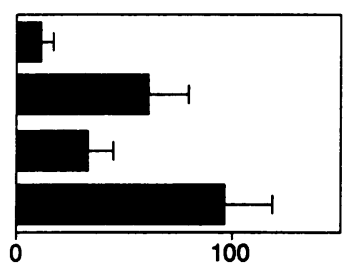

$\lg A$

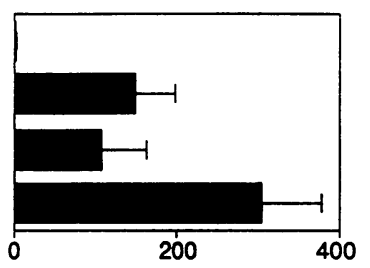

IgG3

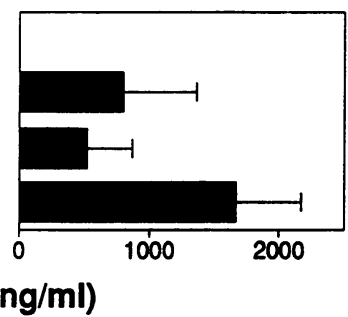

$\operatorname{Ig} E$

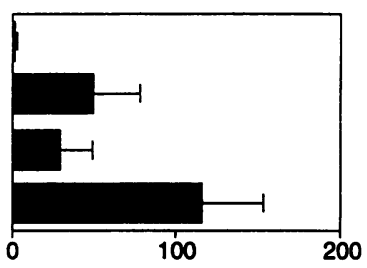

IgG4

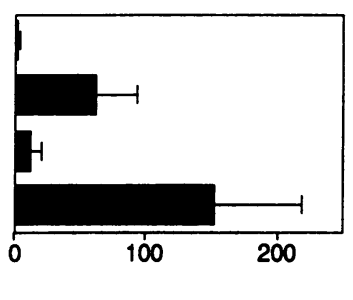

Figure 2. Enhancement of Ig secretion by IL-2 and IL-6. Cord B cells (1.0-2.5 $\times 10^{4}$ per well) were incubated with irradiated cord T cells (1.0 $\times 10^{5}$ per well) and immobilized anti-CD3 in the presence or absence of IL-2 (50 U/ml) or IL-6 (10 U/ml). Supernatants were harvested at multiple time points from 5 to $20 \mathrm{~d}$ for analysis of the Ig secreted. The results presented are the mean \pm SEM of the maximal Ig secreted for each isotype from seven separate experiments. Either IL-2 or IL-6 enhanced the secretion of each Ig isotype above control values $(P<0.05$, Wilcoxon signed rank test). The combination of IL-2 and IL-6 resulted in greater Ig production than that obtained with IL-2 alone for all Ig isotypes except IgG4 and IgE.

were also analyzed. No significant differences were noted in the capacity of IL-2 or IL-4 to alter the rate at which any of the secreted Ig isotypes reached their maximums (data not shown).

IFN- $\gamma$ antagonizes many of the actions of IL-4 $(6,35,36)$. Therefore the effect of IFN- $\gamma$ on the enhanced Ig secretion noted with IL- 2 and IL- 4 was examined (Table II). IFN- $\gamma$ alone had only a minimal effect on Ig secretion. IFN- $\gamma$ did not consistently increase the amount of Ig produced or alter the Ig isotypes secreted in response to IL-2. Moreover, IFN- $\gamma$ did not inhibit the Ig secreted in response to IL-4 or the combination of IL-2 + IL-4 but enhanced the secretion of IgM, IgA, and IgE secreted in response to IL-4 and the secretion of IgM in response to IL-2 + IL-4.

The ability of IL-6 to induce Ig secretion by anti-CD3-stimulated neonatal B and T cells was also examined (Fig. 2). IL-6 induced Ig secretion by most ( 8 of 13 experiments) of the cord $\mathrm{T}$ and $\mathrm{B}$ cell cultures. There was no difference in the pattern of Ig isotypes secreted in response to IL-6 compared to that secreted in response to IL-2. The combination of IL-2 and IL-6 markedly increased the secretion of all Ig isotypes above that noted with either cytokine alone. In each experiment shown in Fig. 2, detailed kinetics of Ig production were analyzed. No reproducible differences were noted in the capacity of IL-2 or IL-6 to alter the rate at which any of the secreted Ig isotypes reached maximal amounts (data not shown). Comparison of the Ig isotypes secreted in response to IL-2 and IL-6 vs. IL-2 and IL-4 from paired experiments indicated that the combination of IL-2 and IL- 6 resulted in more secreted Ig than the combination of IL- 2 and IL-4 but no differences in the Ig isotypes secreted were noted (data not shown). Finally, addition of IL- 6 to cultures supported by IL-4 or IL-2 + IL-4 had no consistent effect on the amount of Ig secreted (data not shown).

The effect of IL-4 and IL-6 on neonatal B cell Ig production is dependent on $I L-2$. Ig production by adult B cells requires IL-2 $(7,20,37)$. The next experiments examined the role of
IL-2 in the production of Ig by neonatal B cells by investigating the ability of antibody to the p55 component of the IL-2 receptor (CD25) to inhibit Ig secretion supported by IL-4 or IL-6. Anti-CD25 inhibited Ig secretion by the anti-CD3-stimulated neonatal $B$ cell and $T$ cells regardless of whether it was in re-

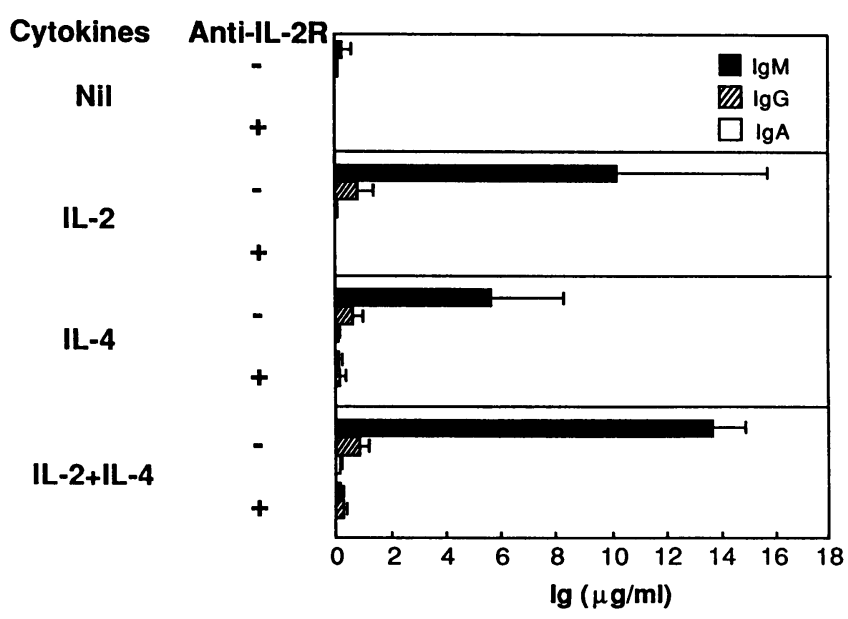

Figure 3. Antibody to the IL-2 receptor (CD25) inhibits Ig secreted in response to IL-4. Cord B cells were incubated with irradiated neonatal $T$ cells and immobilized anti-CD3 in the presence or absence of IL-2 $(50 \mathrm{U} / \mathrm{ml})$ or IL-4 $(100 \mathrm{U} / \mathrm{ml})$. Isotype-matched control antibody or MAb to the p55 component of the IL-2 receptor (CD25) were added to the wells as indicated $(5 \mu \mathrm{g} / \mathrm{ml})$. Supernatants were harvested on day 12 or 13 and assayed for Ig content. The results are expressed as the mean \pm SEM for three experiments. Anti-CD25 inhibited the secretion of IgM, IgG, and IgA promoted by IL-4 and the secretion of IgM and IgA promoted by the combination of IL- 2 and IL-4 (paired $t$ test, $P<0.05$ ). 


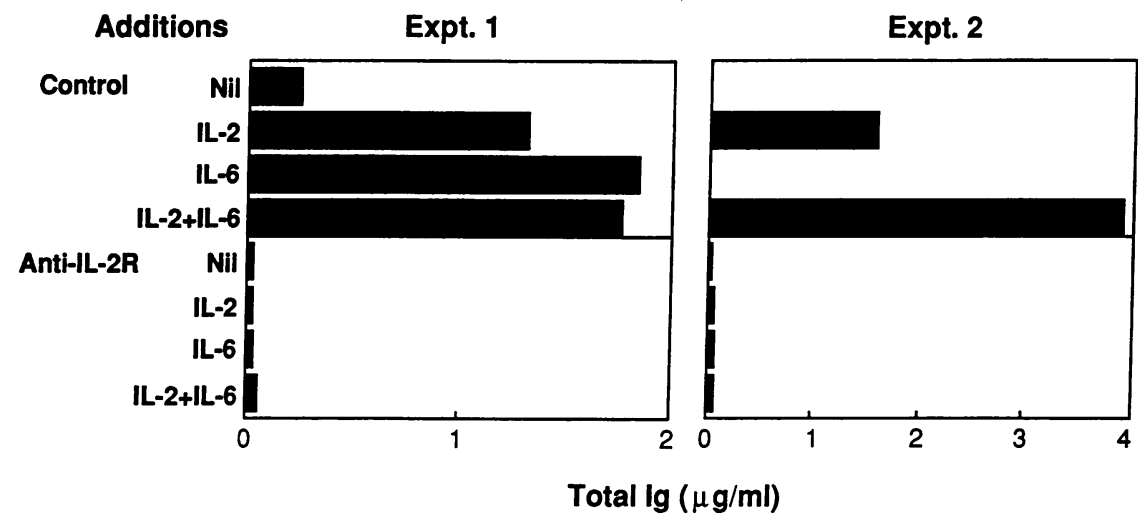

Figure 4. Antibody to the IL-2 receptor (CD25) blocks Ig secretion induced by IL-6. Cord B cells $\left(2.5 \times 10^{4}\right.$ per well) were incubated with irradiated cord $\mathrm{T}$ cells $\left(1.0 \times 10^{5}\right.$ per well $)$ and immobilized anti-CD3 with or without IL-2 $(25 \mathrm{U} / \mathrm{ml})$, IL-6 $(10 \mathrm{U} / \mathrm{ml})$, or anti-CD25 (5 $\mu \mathrm{g} / \mathrm{ml})$. Supernatants were harvested on day 10 for quantitation of the Ig secreted. Isotypematched control antibody did not inhibit Ig secretion. sponse to IL-2 or IL-4 or the combination of IL-2 and IL-4 (Fig. 3). In contrast, MAb to IL-4 had no effect on the amount of Ig produced in response to IL-2, although it markedly inhibited IL-4-induced Ig secretion (Table III).

Antibody to the IL-2 receptor also blocked the secretion of Ig in response to IL-6 either alone or in combination with IL-2 (Fig. 4). In contrast, antibody to IL-6 had no effect on the amount of Ig produced in response to IL-2, although responses induced by IL- 6 were completely inhibited (Fig. 5). These results support the conclusion that IL-2 is required for Ig secretion by the anti-CD3-stimulated neonatal $B$ and $T$ cells whereas neither IL-4 nor IL-6 is absolutely required, although each can amplify responses. The results also imply that the actions of IL- 4 and IL- 6 on neonatal Ig secretion are dependent on the presence of IL-2.

The effects of IL- 4 or IL- 6 could not be explained by an enhancement of $\mathrm{IL}-2$ receptor expression. Fewer than 3\% ( $n$ $=5$ ) of freshly isolated neonatal B or T cells expressed CD25. However, stimulation with immobilized anti-CD3 resulted in a progressive increase in CD25 expression on both B and T cells between 12 and $48 \mathrm{~h}$ (Fig. 6). As shown in Table IV, expression of CD25 was not enhanced on either B or T cells by the additional cytokines, suggesting that enhanced expression of IL-2 receptors on either the B cells or T cells is not a major factor in the ability of the supplemental cytokines to enhance neonatal Ig production.

$I L-4$ promotes the secretion of $I L-2$ by anti-CD3-stimulated neonatal $T$ cells. The next experiments were carried out to determine whether IL-4 had a direct effect on neonatal $T$ cells that might result in increased production of IL-2. As can be seen in Table V, the production of IL-2 by the
anti-CD3-stimulated neonatal $\mathrm{T}$ cells was minimal. Of note, IL-4 significantly enhanced IL-2 production by anti-CD3-activated but not the unstimulated neonatal T cells. IL- 6 also enhanced IL-2 production by anti-CD3-stimulated neonatal $\mathrm{T}$ cells, but the effect was minimal compared to IL-4.

$I L-4$ promotes $I L-6$ production by anti-CD3-stimulated neonatal lymphocytes. The next experiments examined the effect of IL-4 on IL-6 production by neonatal lymphocytes. As can be seen in Table VI, anti-CD3 stimulation alone did not result in IL-6 production by neonatal T cells. IL- 2 did not increase IL- 6 production by the neonatal T cells, whereas IL-4 consistently augmented IL- 6 production by the neonatal $T$ cells although the amount of IL-6 produced was small. The combination of IL-2 and IL-4 had no greater effect on IL-6 production than IL-4 alone. Co-cultures of neonatal B cells and anti-CD3-activated neonatal $\mathrm{T}$ cells produced greater amounts of IL-6 than anti-CD3-stimulated neonatal T cells alone. Supplementation of these cultures with IL -4 consistently increased the production of IL-6.

These results suggested the possibility that IL-4 might indirectly amplify Ig production by neonatal B cells by enhancing production of IL- 6 . Therefore, the effect of an antibody to IL-6 on the capacity of IL-4 to promote Ig production was examined. The data in Fig. 5 indicate that antibody to IL-6 had no consistent effect on IL-4-supported Ig production. These results indicate that IL -4 could enhance IL- 6 production by neonatal lymphocytes although this effect is not essential for IL-4 to promote Ig secretion.

Both IL-2 and IL-4 are required to support Ig secretion by anti-CD3-stimulated neonatal $B$ and $T$ cells in the presence of cyclosporin A. Cyclosporin was used to prevent cytokine pro-

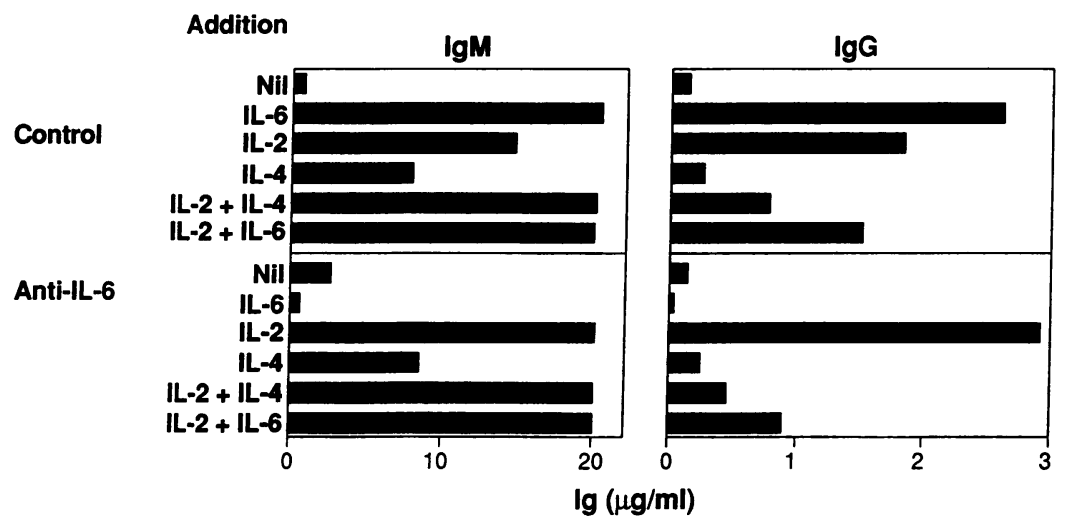

Figure 5. Antibody to IL-6 does not inhibit the secretion of Ig induced by IL-4. Anti-CD3-stimulated neonatal $B$ cells $\left(2.5 \times 10^{4}\right.$ per well $)$ and irradiated T cells $\left(1 \times 10^{5}\right.$ per well $)$ were incubated with or without supplemental cytokines (IL-2, 50 $\mathrm{U} / \mathrm{ml} ; \mathrm{IL}-4,100 \mathrm{U} / \mathrm{ml}$; IL-6, $10 \mathrm{U} / \mathrm{ml}$ ) and neutralizing antibody to IL-6 (1:150 dilution). Supernatants were harvested after $15 \mathrm{~d}$ for quantitation of secreted Ig. One of two similar experiments is shown. Control rabbit IgG had no inhibitory effect. 


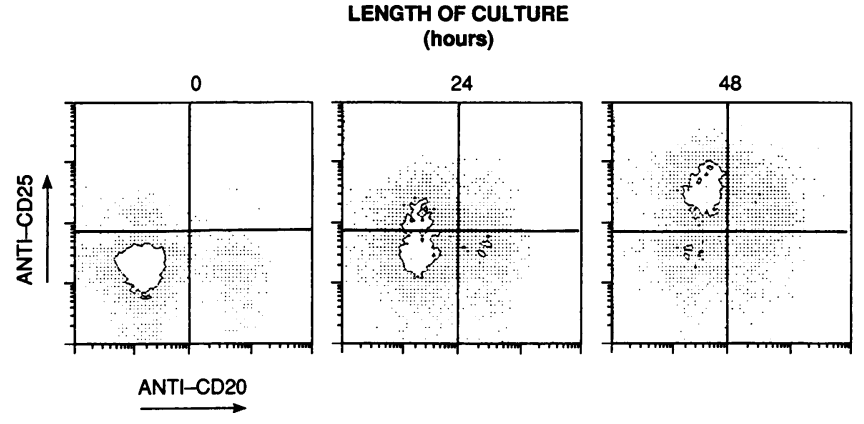

Figure 6. Induction of $\mathrm{CD} 25$ expression by anti-CD3 stimulation. Irradiated neonatal T cells $\left(2 \times 10^{6}\right)$ and B cells $\left(1 \times 10^{6}\right)$ were incubated with immobilized anti-CD3. Cells were stained before culture and at varied time points after the initiation of culture with antiCD20-FITC to distinguish B cells and T cells and with anti-CD25-PE, fixed, and analyzed by fluorescence-activated cell sorter. Gates were set using control antibodies.

duction in order to examine the effects of supplemental cytokines in the absence of endogenously produced cytokines (38). In the presence of cyclosporin, IL-2 alone was not sufficient to induce Ig secretion (Table VII). IL-4 alone was also not able to enhance Ig secretion consistently. In the presence of cyclosporin, however, the combination of IL-2 and IL-4 routinely resulted in Ig secretion. These results indicate that in the presence of cyclosporin both IL-2 and IL-4 were necessary to induce Ig secretion by the anti-CD3-stimulated neonatal T and B cells. In contrast, IL-6 alone did not support Ig secretion, and did not enhance Ig secretion in the presence of IL-2 or IL-4. It should be pointed out that not all of the cyclosporin-induced inhibition of Ig secretion could be reversed with the addition of cytokines, suggesting that other factors may be required or that cyclosporin has effects other than inhibition of cytokine production.

Effects of cytokines on $B$ and $T$ cell responses. The next experiments examined the impact of IL-2 or IL-4 on antiCD3-activated neonatal B and T cells. Neonatal B cells were cultured with anti-CD3-stimulated T cells for $48 \mathrm{~h}$ and isolated, and their ability to respond to IL-2 or IL-4 was examined (Table VIII). IL-2 supported neonatal B cell Ig secretion,

Table III. Anti-IL-4 Does Not Inhibit IL-2-induced Ig Secretion

\begin{tabular}{lcccc}
\hline & & \multicolumn{3}{c}{ Ig isotype secreted } \\
\cline { 3 - 5 } Addition & Anti-IL-4 & IgM & IgG & IgA \\
\hline \multirow{4}{*}{ Nil } & & & $n g / m l$ & \\
& - & $<24$ & $<12$ & $<12$ \\
IL-2 & + & $<24$ & $<12$ & $<12$ \\
& - & 7371 & 573 & 102 \\
IL-4 & + & 8505 & 654 & 144 \\
& - & 5913 & 1434 & 159 \\
& + & 42 & 15 & $<12$
\end{tabular}

Neonatal $B$ and $T$ cells were incubated with anti-CD3 with or without IL-2 $(50 \mathrm{U} / \mathrm{ml})$ or IL-4 $(100 \mathrm{U} / \mathrm{ml})$ in the presence of control antibody or MAb to IL-4 $(1 \mu \mathrm{g} / \mathrm{ml})$. Supernatants were harvested on day 12 for quantitation of Ig by ELISA.
Table IV. Induction of IL-2 Receptor (CD25) by Anti-CD3

\begin{tabular}{|c|c|c|c|c|c|c|c|}
\hline \multirow[b]{3}{*}{ Cell source } & \multirow{3}{*}{$\begin{array}{l}\text { Supplemental } \\
\text { cytokines }\end{array}$} & \multicolumn{6}{|c|}{ Donor } \\
\hline & & \multicolumn{2}{|c|}{1} & \multicolumn{2}{|c|}{2} & \multicolumn{2}{|c|}{3} \\
\hline & & $\%+$ & MFI & $\%+$ & MFI & $\%+$ & MFI \\
\hline \multirow[t]{6}{*}{ B cells } & Nil & 24 & 170 & 73 & 365 & 18 & 113 \\
\hline & IL-2 & 18 & 162 & 69 & 371 & 22 & 124 \\
\hline & IL-4 & 25 & 222 & 70 & 538 & 20 & 96 \\
\hline & IL-2 + IL-4 & 31 & 221 & 84 & 572 & 24 & 105 \\
\hline & IL-6 & 31 & 172 & 86 & 519 & 21 & 123 \\
\hline & IL-2 + IL-6 & 38 & 163 & 75 & 409 & 31 & 127 \\
\hline \multirow[t]{6}{*}{$\mathrm{T}$ cells } & Nil & 24 & 164 & 72 & 485 & 50 & 148 \\
\hline & IL-2 & 24 & 150 & 75 & 610 & 57 & 172 \\
\hline & IL-4 & 20 & 170 & 67 & 783 & 58 & 160 \\
\hline & IL-2 + IL-4 & 24 & 153 & 75 & 751 & 69 & 191 \\
\hline & IL-6 & 26 & 154 & 79 & 686 & 51 & 159 \\
\hline & IL-2 + IL-6 & 30 & 156 & 77 & 670 & 61 & 197 \\
\hline
\end{tabular}

Neonatal B cells $\left(1 \times 10^{6}\right)$ and irradiated T cells $\left(2 \times 10^{6}\right)$ were stimulated with immobilized anti-CD3. Cells were harvested at $24 \mathrm{~h}$ (expt. 1) and $48 \mathrm{~h}$ (exptr. 2 and 3) and stained with MAb to CD25-PE and CD20-FITC for analysis of IL-2 receptor (CD25) expression on $B$ and $T$ cell populations by FACS. The data indicate the percentage of positively staining cells (\%) and the mean fluorescence intensity (MFI) of the stained cells. Less than 2\% of freshly isolated B and T cells expressed CD25.

whereas IL-4 was much less effective in supporting Ig secretion by the activated B cells even in the presence of IL-2. The effect of IL- 2 and IL- 4 on the capacity of anti-CD3-activated T cells to provide help for neonatal B cells was also investigated (Table IX). Neonatal T cells stimulated with anti-CD3 were unable to support neonatal B cell Ig secretion. However, the presence of IL-4 and to a lesser extent IL-2 during T cell activation with anti-CD3 resulted in an enhanced ability of the neonatal $T$

Table V. Effect of Supplemental Cytokines on IL-2 Production by Neonatal $T$ Cells

\begin{tabular}{ccrcr}
\hline & & \multicolumn{3}{c}{ IL-2 production } \\
\cline { 3 - 5 } Anti-CD3 & Additions & \multicolumn{1}{c}{ Expt. 1 } & Expt. 2 & Expt. 3 \\
\hline \multirow{4}{*}{$\left.{ }^{3} H\right]$ TdR } & $\begin{array}{c}\text { incorporation by } \\
\left(\text { cpm } \times 10^{-3}\right)\end{array}$ \\
& & \multicolumn{3}{c}{ cTLL cells } \\
- & Nil & $2.1 \pm 0.6$ & $0.1 \pm 0.0$ & $0.2 \pm 0.0$ \\
& IL-4 & $0.7 \pm 0.4$ & $1.1 \pm 0.7$ & $0.2 \pm 0.0$ \\
& IL-6 & $0.8 \pm 0.4$ & $0.2 \pm 0.0$ & $0.7 \pm 0.7$ \\
& Nil & $0.8 \pm 0.1$ & $1.2 \pm 0.1$ & $1.5 \pm 0.7$ \\
& IL-4 & $11.2 \pm 1.1$ & $25.3 \pm 1.0$ & $19.6 \pm 0.8$ \\
& IL-6 & $2.7 \pm 0.1$ & $3.0 \pm 0.6$ & $2.8 \pm 0.7$ \\
& & & &
\end{tabular}

Irradiated cord $\mathrm{T}$ cells $\left(1.0 \times 10^{5}\right.$ per well $)$ were incubated with or without immobilized anti-CD3 in the presence or absence of IL-4 $(100 \mathrm{U} / \mathrm{ml})$ or IL-6 $(10 \mathrm{U} / \mathrm{ml})$. Anti-CD25 $(5 \mu \mathrm{g} / \mathrm{ml})$ was added to all wells to prevent absorption of IL-2. Supernatants were harvested after $72 \mathrm{~h}$ and were assayed for IL-2 production. Data are shown as the $\left[{ }^{3} \mathrm{H}\right]$ thymidine incorporation by CTLL cells. Both IL-4 and IL-6 increased IL-2 production above control and the increase with IL-4 was greater than that induced by IL-6 $(P \leq 0.03$, paired $t$ test $)$. 
Table VI. IL-6 Production by Anti-CD3-stimulated Lymphocytes

\begin{tabular}{llrrrr}
\hline & & \multicolumn{4}{c}{ Additions } \\
\cline { 3 - 6 } Expt. & Cell source & Nil & IL-2 & IL-4 & IL-2+4 \\
\hline \multirow{3}{*}{1} & & \multicolumn{4}{c}{$p g / m l$} \\
& T & 21 & $<10$ & 30 & ND \\
2 & B + T & 26 & 94 & 388 & ND \\
& T & $<10$ & $<10$ & 11 & 59 \\
3 & B + T & 120 & 123 & 198 & 163 \\
& T & $<10$ & $<10$ & 44 & 34 \\
4 & B + T & 140 & 30 & 290 & 320 \\
5 & B + T & $<10$ & ND & 240 & ND \\
& B + T & $<10$ & ND & 160 & ND \\
\hline
\end{tabular}

Irradiated neonatal $\mathrm{T}$ cells $\left(1.0 \times 10^{5}\right.$ per well) were cultured with or without neonatal B cells $\left(2.5 \times 10^{4}\right.$ per well $)$ in the presence or absence of IL-2 $(50 \mu / \mathrm{ml})$ or IL-4 $(100 \mu / \mathrm{ml})$ with immobilized antiCD3. Supernatants were harvested after a 10-d incubation for determination of IL- 6 by ELISA. Expts. 4 and 5 examined IL- 6 production by neonatal $B\left(1 \times 10^{6} / \mathrm{ml}\right)$ and neonatal T cells $\left(2 \times 10^{6} / \mathrm{ml}\right)$ with and without IL-4 after a 72-h incubation. ND, not done.

cells to support Ig secretion by the neonatal B cells. Similar results were noted when cyclosporin was included during the activation of the T cells, implying that the effects of IL- 4 or IL-2 could not be explained by an indirect effect on cytokine production by the $T$ cells (data not shown). The activated $T$ cells did not support neonatal B cell Ig secretion in the absence of supplemental IL-2, suggesting that differences in the amount of IL-2 secretion did not account for the enhanced helper function. The effect of IL-4 on T cell preactivation could also be demonstrated in the presence of cyclosporin suggesting that cytokine production was not essential for the effect (data not shown). These results suggest that IL-4 directly enhances neonatal T cell helper function and that the effect of IL-4 on neonatal B cell Ig secretion may be indirect.

Table VIII. Reversal of Cyclosporin-induced Inhibition of Ig Secretion by Cytokines

\begin{tabular}{lcrrr}
\hline & \multicolumn{4}{c}{ Total Ig secreted } \\
\cline { 2 - 5 } \multicolumn{1}{c}{ Addition } & Expt. 1 & Expt. 2 & Expt. 3 & Expt. 4 \\
& \multicolumn{5}{c}{$n g / m l$} \\
Nil & $<12$ & $<12$ & 12 & $<12$ \\
IL-2 & $<12$ & $<12$ & 12 & $<12$ \\
IL-4 & $<12$ & $<12$ & 114 & $<12$ \\
IL-2 + IL-4* & 353 & 336 & 435 & 1,758 \\
IL-6 & $<12$ & $<12$ & $<12$ & $<12$ \\
IL-2 + IL-6 & $<12$ & 12 & $<12$ & $<12$ \\
IL-4 + IL-6 & ND & $<12$ & 72 & $<12$ \\
IL-2 + IL-4 + IL-6 & ND & 348 & 417 & 1,521 \\
& & & & \\
\hline
\end{tabular}

Cord B cells $\left(2.5 \times 10^{4}\right.$ per well $)$ were incubated with irradiated cord $\mathrm{T}$ cells $\left(1-1.5 \times 10^{5}\right.$ per well $)$ in the presence of immobilized anti-CD3 and cyclosporin $A(100 \mathrm{ng} / \mathrm{ml})$ with or without the addition of IL-2 $(50 \mathrm{U} / \mathrm{ml}), \mathrm{IL}-4(100 \mathrm{U} / \mathrm{ml})$, or IL-6 $(10 \mathrm{U} / \mathrm{ml})$. Supernatants were harvested for quantitation of Ig secretion on days 12-15. ND, not done. ${ }^{*}$ Mean percentage of control response $53 \pm 32 \%$.
Table VIII. Cytokine Responsiveness of Neonatal B Cells Preactivated with Anti-CD3-stimulated T Cells

\begin{tabular}{lrrrr}
\hline & \multicolumn{4}{c}{ Addition to B cells } \\
\cline { 2 - 5 } Expt. & NIL & IL-2 & IL-4 & IL-2 + IL-4 \\
\hline & \multicolumn{4}{c}{$n g / m l$} \\
1 & 159 & 1,592 & 162 & 651 \\
2 & 26 & 351 & $<12$ & 646 \\
3 & $<12$ & 183 & $<12$ & 132 \\
\hline
\end{tabular}

Cord B cells $1 \times 10^{6} / \mathrm{ml}$ were preincubated with anti-CD3-activated adult $T$ cells for $48 \mathrm{~h}$. The B cells were then depleted of $T$ cells and incubated $\left(2.5 \times 10^{4}\right.$ per well) alone or with IL-2 $(50 \mathrm{U} / \mathrm{ml})$ or IL-4 $(100 \mathrm{U} / \mathrm{ml})$ for an additional $10 \mathrm{~d}$.

Supplemental cytokines do not cause the loss of CD45RA expression. Previous studies have suggested that naive CD45RA expressing cells cannot provide help for B cells (39). Therefore, it was possible that the effect of the supplemental cytokines was to promote differentiation or outgrowth of $\mathrm{CD} 5 \mathrm{RA}^{-}$memory cells that could then provide B cell help. As shown in Fig. 7, >95\% of the neonatal lymphocytes were $\mathrm{CD} 45 \mathrm{RA}^{+}$at the initiation of culture. Neonatal T cells stimulated with immobilized anti-CD3 with or without supplemental cytokines and harvested after various lengths of culture (2-15 d) remained CD45RA ${ }^{+}$. These results suggest that in these cultures, help is provided by CD45RA ${ }^{+}$naive $T$ cells and that differentiation to $\mathrm{CD}_{45 \mathrm{RA}^{-}}$memory $\mathrm{T}$ cells did not occur.

\section{Discussion}

Immobilized anti-CD3 is a powerful inducer of Ig secretion by adult lymphocytes $(40,41)$. Detailed analysis of the Ig secreted by anti-CD3-stimulated adult $B$ and $T$ cells demonstrated the production of all Ig isotypes without supplemental cytokines. Supplemental IL-2, IL-4, or IL-6 did not enhance Ig produc-

Table IX. Role of Cytokines in the Induction of Helper Activity by Neonatal T Cells

\begin{tabular}{lccr}
\hline & \multicolumn{3}{c}{ Secretion of Ig } \\
\cline { 2 - 4 } $\begin{array}{c}\text { Cytokine present during } \\
\text { T cell activation }\end{array}$ & Expt. 1 & Expt. 2 & Expt. 3 \\
\hline & & $n g / m l$ & \\
Nil & $<12$ & 15 & 28 \\
IL-2 & 243 & 15 & 109 \\
IL-4 & 420 & 300 & 1836 \\
IL-2 + IL-4 & ND & 210 & 1449 \\
& & & \\
\hline
\end{tabular}

Irradiated T cells $\left(1 \times 10^{6} / \mathrm{ml}\right)$ were preincubated with immobilized anti-CD3 with or without IL-2 $(50 \mathrm{U} / \mathrm{ml})$ or IL-4 $(100 \mathrm{U} / \mathrm{ml})$ for 24 $h$. The $T$ cells were then harvested, washed, and reincubated at 1.0 $\times 10^{5}$ per well with $2.5 \times 10^{4}$ autologous cord B cells and IL-2 (50 $\mathrm{U} / \mathrm{ml}$ ). No Ig secretion was induced when $B$ cells were co-cultured with $T$ cells that had been preincubated with cytokines but without anti-CD3. In the absence of IL-2 in the second culture, there was minimal secretion of Ig. ND, not done. 


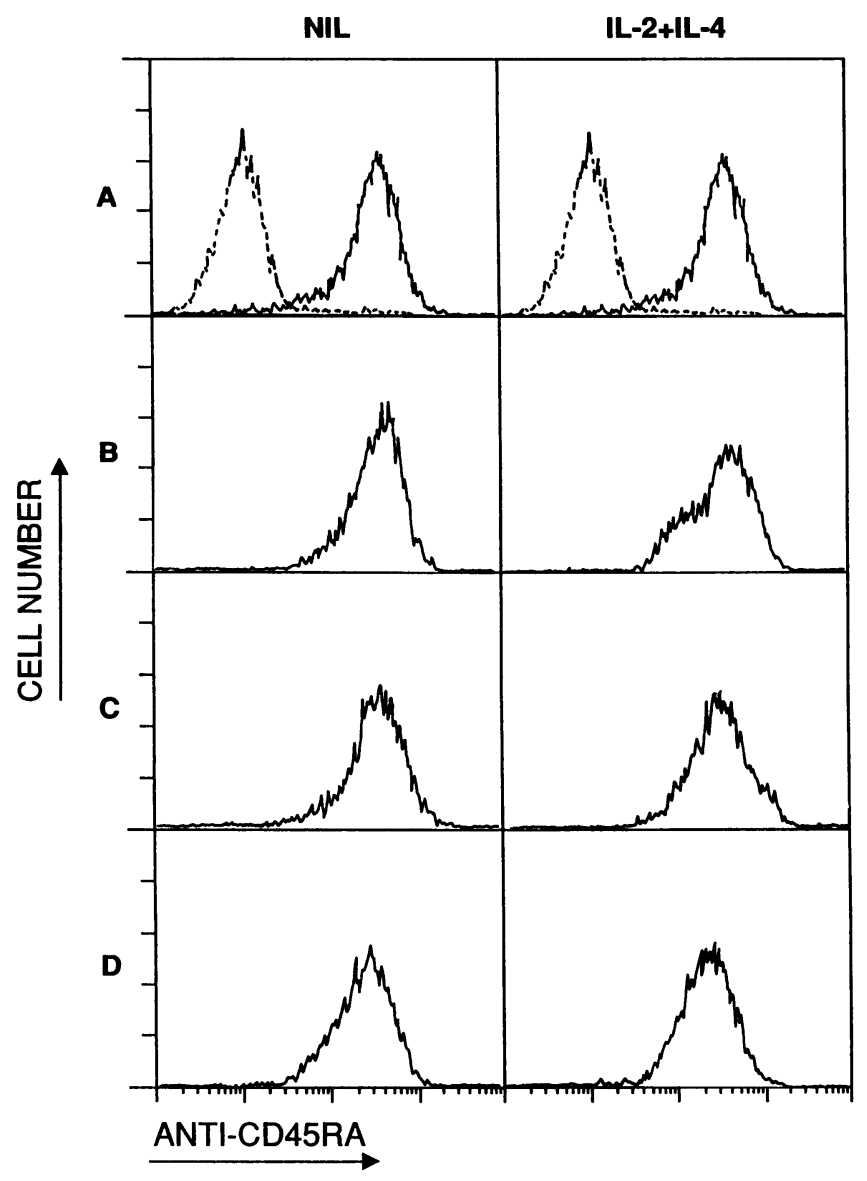

Figure 7. Anti-CD3 stimulation with or without supplemental cytokines does not induce loss of CD45RA. Anti-CD3-stimulated neonatal $T$ cells were stained for CD45RA expression before culture and after varying lengths of incubation and analyzed by fluorescence activated cell sorting. $(A)$ Control (dashed line) and CD45RA (solid line) expression of the cells before to culture. $(B-D) C D 45 R A$ expression of neonatal T cells at days 2,4 , and 7 , respectively in response to stimulation with (left) anti-CD3 alone and (right) anti-CD3 with IL-2 $(50 \mathrm{U} / \mathrm{ml})$ and IL-4 $(100 \mathrm{U} / \mathrm{ml})$. Representative data from one of four experiments are shown.

tion, with the exception that IgE secretion was increased in response to either IL-2 or IL-4, but not IL-6. These results support the conclusion that anti-CD3 stimulation of adult $T$ cells is sufficient to result in maximal Ig secretion by adult $B$ cells. By contrast, anti-CD3-activated neonatal T cells are deficient in the capacity to support Ig production by adult or neonatal B cells (4). Although neonatal T cells are reported to secrete IL-2, their ability to produce a number of other cytokines including IL-4 and IFN- $\gamma$ is deficient (10-15). Therefore, the capacity of exogenous cytokines to promote Ig production by neonatal lymphocytes was explored.

In order to evaluate $T$ cell-B cell collaboration, it was necessary to prevent the suppressive effect of the neonatal $T$ cells by irradiating them, as previously described (4). Irradiation decreased, but did not prevent IL-2 production. However, in contrast to adult cultures, endogenous production of IL-2 was insufficient for the support of Ig production by neonatal B cells. Provision of large concentrations of exogenous IL-2 resulted in the induction of Ig secretion, suggesting that the antiCD3-stimulated neonatal lymphocytes were less responsive to
IL-2 or required additional signals which could be induced or bypassed by the provision of large amounts of IL- 2 .

We have previously reported that IgG and a small amount of IgA were secreted by anti-CD3-stimulated neonatal lymphocytes cultured with supplemental IL-2 (4). It is likely that production of these Ig isotypes results from switch recombination since the overwhelming majority, if not all, neonatal B cells express surface IgM. We report here that all four subclasses of IgG can be produced by maximally activated neonatal B and T cells, but that IgG 1 and IgG3 are produced predominantly. Compared to responses obtained with adult lymphocytes, neonatal lymphocytes secrete proportionately more IgG3 and less IgG2 and IgA. These results are consistent with the delay in the development of serum levels of these Ig isotypes $(42,43)$. Of note, the $\gamma 3$ heavy chain is the most 5 ' of the $\gamma$ heavy-chain genes followed by $\gamma 1, \gamma 2$, and $\gamma 4$, suggesting that the disproportionate increase in IgG3 secretion by the neonatal lymphocytes may be consistent with a tendency to switch from IgM to the most proximal $\gamma$ heavy chain gene (44). This is not an exclusive switch however, as IgG1 remains the predominant IgG subclass produced and the cells also produce small amounts of IgG2 and IgG4 as well as IgA and IgE.

The current work addressed the possibility that cytokines other than IL-2 may be important for the induction of Ig secretion and for the production of individual Ig isotypes by neonatal lymphocytes. IL-4 has major effects on T cell proliferation as well as regulatory effects on human B cell growth and differentiation (5-7). IL-4 has also been shown to facilitate IgE synthesis and secretion $(8,15,45,46)$. Naive adult $T$ cells and neonatal $T$ cells do not produce IL-4 (10-13). Supplementation of anti-CD3-stimulated neonatal T and B cells with IL-4 resulted in the production of all major Ig isotypes including but not exclusively IgE. IL-4 enhanced the production of Ig above that obtained with IL-2 alone, without altering the Ig isotypes secreted.

Neonatal lymphocytes and naive adult $\mathrm{T}$ cells are reported to be deficient in their ability to produce $\operatorname{IFN}-\gamma(13,16,47)$. IFN- $\gamma$ does not support Ig secretion by Staphylococcus aureusactivated adult $B$ cells but enhances IL- 2 responsiveness and Ig secretion supported by IL-2 (37). It has also been reported to regulate Ig isotype production in the mouse and to antagonize some of the actions of IL-4 $(6,14,15,35,36)$. IFN- $\gamma$ alone did not consistently result in Ig secretion or enhance Ig secretion in combination with IL-2 by the anti-CD3-stimulated neonatal lymphocytes. IFN- $\gamma$ did not inhibit Ig secretion supported by IL-4 but rather tended to enhance Ig secretion induced by IL-4, but did not alter the Ig isotypes. These results suggest that as with adult lymphocytes, IFN- $\gamma$ plays a modest role in enhancing Ig production in an isotype nonspecific manner and, importantly, does not interfere with the action of IL-4 on the neonatal lymphocytes.

IL-6 also plays an important role in B cell Ig secretion (19, 20). A recent report suggested that IL-6 was required for primary immunoglobulin responses in the mouse (48). Previous reports suggest that IL- 6 is made by both neonatal T and B cells in response to mitogens (49). However, two recent reports suggest that production of IL- 6 by naive $T$ cells stimulated with anti-CD2 or anti-CD3 may be deficient $(13,50)$. Therefore, the action of IL- 6 on neonatal Ig production stimulated by anti-CD3 was also investigated. IL-6 alone resulted in an inconsistent induction of Ig secretion by the anti-CD3-stimulated neonatal B cells but consistently augmented Ig secretion 
in response to IL-2 without a significant effect on the pattern of Ig isotypes secreted.

These results suggested that both IL-4 and IL-6 appear to be capable of enhancing Ig secretion. Because they are produced in deficient amounts by neonatal lymphocytes, the limited amounts of these cytokines could account for deficient humoral responses by neonates. Since neonatal cells are largely composed of naive cells, production of large amounts of Ig from postswitch memory cells is not observed and therefore cannot mask subtle effects of cytokines on a small fraction of cells undergoing switch recombination. Despite this, however, only minor differences in the Ig isotypes secreted were noted with the individual cytokines. Clear-cut evidence for an isotype-specific effect on neonatal B cell Ig secretion could not be demonstrated with any of the cytokines studied. Therefore, the results are most consistent with the conclusion that these cytokines do not exert isotype specific effects on human B cells activated with anti-CD3-stimulated $T$ cells.

Our previous work suggested that neither IL -4 or IL-6 alone supported the production of Ig by $S$. aureus-stimulated adult B cells $(6,7,20)$. Inhibition of the IL-4- and IL-6-induced Ig secretion by antibody to CD25 supported the conclusion that IL-2 was required for the induction of Ig secretion by neonatal $B$ cells as well. Similar results were obtained with a neutralizing rat MAb to human IL-2 (data not shown), indicating that these results were not related to an inhibitory effect of the anti-CD25 on the responsiveness of the cells. The essential role of IL-2 in promoting Ig production by neonatal B cells was confirmed in preliminary experiments indicating that preactivated neonatal B cells produced Ig in response to IL-2 but not IL-4 or IL-6. These results demonstrate that like adult B cells, neonatal B cells require IL-2 to produce Ig.

A number of effects of IL-4 were documented that could explain its capacity to enhance Ig production by neonatal B cells. First it dramatically increased IL-2 production by antiCD3-activated neonatal $\mathrm{T}$ cells, although it had no effect on IL-2R expression by either neonatal $T$ or $B$ cells. This effect on IL-2 production is consistent with a previous report showing that IL- 4 enhanced IL- 2 production by mitogen-stimulated adult $T$ cells (5). IL-4 exerted other effects in this model system that also contributed to its capacity to enhance Ig production. Thus, for example, the presence of IL-4 during activation of neonatal $T$ cells with anti-CD3 enhanced the subsequent ability of the activated neonatal T cells to support neonatal B cell Ig secretion independently of effects on cytokine production. These results support the conclusion that IL-4 directly enhanced the capacity of activated neonatal $T$ cells to collaborate with B cells as well as produce cytokines necessary for B cell differentiation. IL -4 also enhanced production of IL -6 by neonatal lymphocytes. This was particularly noteworthy in co-cultures of anti-CD3-activated neonatal $T$ and $B$ cells. The cell of origin of the IL-6 was not determined in these mixed cell cultures. It is clear that IL- 4 can augment IL- 6 production by anti-CD3-activated neonatal $\mathrm{T}$ cells but in the mixed cultures IL-4 could have amplified IL- 6 production from B cells as well. In this regard, a recent report suggests that IL- 4 may directly promote IL- 6 production by resting purified adult human B cells (51). For the current studies, the important finding was that even though IL- 4 induced IL- 6 production from neonatal lymphocytes, the induction of IL-6 production could not account for the effects of IL-4 on anti-CD3-stimulated Ig production by neonatal lymphocytes. Thus, a neutralizing antibody to
IL-6 which totally inhibited the Ig secretion induced by IL-6, had minimal effects on the Ig produced in response to IL-4.

A unique effect of IL-4 on anti-CD3-stimulated Ig production was also demonstrated in the presence of cyclosporin $A$. In the absence of endogenous cytokine production, IL-4 did not support Ig secretion by the neonatal B cells. However, the combination of exogenous IL-2 and IL-4 consistently resulted in Ig secretion in the presence of cyclosporin. These results confirmed that the IL-4 induced Ig secretion was dependent on the presence of IL-2. These results are consistent with the demonstration by Renz et al. (52) that IL-4 could not induce IgE secretion by adult mononuclear cells in the presence of cyclosporin unless IL-2 was also present. The current finding extends those results by showing a similar IL-2 dependence of IL-4 effects in neonatal lymphocytes and that this requirement for IL-2 extends to induction of all Ig isotypes.

Of importance, IL-2 alone could not promote Ig secretion by cyclosporin blocked neonatal lymphocytes. Ig secretion was only noted when cells were co-stimulated by IL-2 and IL-4. It is not certain that this represents a physiologic requirement or a requirement imposed by cyclosporin since IL-4 is not thought to be secreted by neonatal T cells (10-13) and a MAb to IL-4 does not consistently block IL-2-supported Ig secretion by neonatal lymphocytes. Moreover, the amount of Ig secreted by cyclosporin-blocked cells in the presence of IL-2 and IL-4 is much less than that produced by control cells supported by the same cytokines, suggesting either that there are additional inhibitory effects of cyclosporin in these cultures or that an as yet unidentified endogenously produced cytokine is necessary for maximal Ig secretion by neonatal lymphocytes. If the latter is the case, IL-4 may partially substitute for its action. Regardless of the exact explanation, the results suggest that IL -4 promoted neonatal T-B cell interactions independently of its effects on cytokine production. IL- 4 has been reported to promote conjugate formation between murine $T$ cells and $B$ cells and to enhance the expression of a number of molecules including MHC class II, CD40, and CD23, which may be involved in T and B cell interactions $(35,53-57)$. Therefore, the ability of IL-4 to upregulate expression of some of these molecules may contribute to its capacity to promote $\mathrm{T}$ cell dependent $\mathrm{B}$ cell activation.

Neonatal T cells are largely CD45RA ${ }^{+}$naive $T$ cells. Therefore, it was possible that anti-CD3 stimulation caused these cells to differentiate in vitro or that IL-4 enhanced this differentiation. Anti-CD3 stimulation of the neonatal T cells with or without IL-4 did not result in a significant decrease in CD45RA expression even after prolonged culture periods. As $\mathrm{CD} 4 \mathrm{RA}^{-}$cells account for $<3 \%$ of the irradiated $\mathrm{T}$ cells utilized in the current cultures it is unlikely that this small number of CD45RA- cells accounted for the results presented since 1 $\times 10^{4}$ adult memory $\mathrm{T}$ cells minimally support Ig production by adult B cells in this culture system (40). These results support the conclusion that the $T$ cell help in these cultures originated from $\mathrm{CD}_{45 \mathrm{RA}^{+}}$cells and that anti-CD3 stimulation with or without supplemental cytokines did not cause outgrowth of CD45RA ${ }^{-}$cells or differentiation of $\mathrm{CD} 45 \mathrm{RA}^{+}$cells to CD45RA- memory cells within the time frame of these experiments. These results are consistent with the demonstration

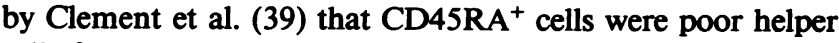
cells for adult $B$ cells but demonstrate that they can provide help if maximally stimulated with anti-CD3 and supplemental cytokines are provided (39). 
IL-6 did not support Ig secretion in the presence of cyclosporin with or without IL-2. These results demonstrate important differences in the effects of IL-4 and IL-6 on neonatal Ig secretion. They also support the conclusion that IL-6 production is not necessary for all of the effects of IL-4, because IL-6 could not substitute for IL-4 in supporting Ig secretion in combination with IL-2 in cyclosporin-blocked cultures. It is also important to note that the combination of IL-6 and IL- 4 did not support Ig secretion in the presence of cyclosporin suggesting that IL-6 does not induce Ig secretion in the absence of IL-2. The finding that IL-6 did not enhance Ig secretion in cyclosporin-blocked cultures supported by IL-2 or by IL-2 and IL-4 suggests that cyclosporin may inhibit the capacity of neonatal cells to respond to IL-6, or alternatively, IL-6 may indirectly increase Ig production by inducing the production of another cytokine. Additional experiments are currently examining these possibilities. The important conclusions from this study, however, are that although IL-6 can increase Ig production by neonatal lymphocytes, it cannot exert its effect in the absence of IL-2 and does not appear to be essential for the induction of Ig secretion.

In summary, anti-CD3-stimulated neonatal lymphocytes are deficient in their ability to produce IL-4 and IL-6. However, both of these cytokines are able to promote Ig secretion by anti-CD3-stimulated neonatal lymphocytes but neither appears to exert a specific effect on the pattern of Ig isotype secreted. IL-2 appears to be essential for Ig secretion by the neonatal B cells. IL-4 has major effects on T cell helper function including facilitation of cytokine production and possibly enhancement of the capacity to provide noncytokine signals required for B cell activation. IL-6 does not appear to be essential for neonatal Ig secretion but enhances Ig secretion in an IL-2dependent manner. These results indicate that deficient cytokine production by neonatal lymphocytes is not coupled with inability to respond to supplemental cytokines and suggest approaches to enhance the primary humoral response of neonates.

\section{Acknowledgments}

We would like to thank Ms. Bonnie Ferguson-Darnell and Ms. Diana Shipman for their excellent technical assistance, Dr. Lynette Casey, Melanie King and Valencia Hoffman for procurement of the cord blood samples, and Ms. Alice Wiggins for preparation of the manuscript.

This work was supported by National Institutes of Health grants DK-01620, AR-09989, and AR-36169.

\section{References}

1. Gathings, W. E., H. Kubagawa, and M. D. Cooper. 1981. A distinctive pattern of B cell immaturity in perinatal humans. Immunol. Rev. 57:107-126.

2. Wu, L. Y. F., A. Blanco, M. D. Cooper, and A. R. Lawton. 1976. Ontogeny of B-lymphocyte differentiation induced by pokeweed mitogen. Clin. Immunol. Immunopathol. 5:208-217.

3. Haywood, A. R., and A. R. Lawton. 1977. Induction of plasma cell differentiation of human fetal lymphocytes: evidence for functional immaturity of $T$ and B cells. J. Immunol. 119:1213-1217.

4. Splawski, J. B., D. F. Jelinek, and P. E. Lipsky. 1990. Delineation of the functional capacity of human neonatal lymphocytes. J. Clin. Invest. 87:545-553.

5. Mitchell, L., L. Davis, and P. Lipsky. 1989. Promotion of human T lymphocyte proliferation by IL-4. J. Immunol. 142:1548-1557.

6. Jelinek, D. F., and P. E. Lipsky. 1988. Inhibitory influence of IL-4 on human B cell responsiveness. J. Immunol. 141:164-173.
7. Splawski, J. B., D. F. Jelinek, and P. E. Lipsky. 1989. Immunomodulatory role of interleukin 4 on the secretion of immunoglobulin by human B cells. $J$. Immunol. 142:1569-1575.

8. Pene, J., F. Rousset, F. Briere, I. Chretien, J. Bonnefoy, H. Spits, T. Yokota, N. Arai, K. Arai, and J. Banchereau. 1988. IgE production by normal human lymphocytes is induced by interleukin 4 and suppressed by interferons $\gamma$ and $\alpha$ and prostaglandin E2. Proc. Natl. Acad. Sci. USA. 85:6880-6884.

9. Jabara, H., S. Ackerman, D. Vercelli, T. Yokota, K. Arai, J. Abrams, A. Dvorak, M. Lavigne, J. Banchereau, J. De Vries, et al: 1988. Induction of interleukin 4-dependent IgE synthesis and interleukin 5-dependent eosinophil differentiation by supernatants of a human helper T cell clone. J. Clin. Immunol. 8:437-446.

10. Andersson, U., J. Andersson, A. Lindfors, K. Wagner, G. Moller, and C. H. Heusser. 1990. Simultaneous production of interleukin 2, interleukin 4 and interferon- $\gamma$ by activated human blood lymphocytes. Eur. J. Immunol. 20:15911596.

11. Powers, G., A. Abbas, and R. Miller. 1988. Frequencies of IL-2- and IL-4-secreting $\mathrm{T}$ cells in naive and antigen stimulated lymphocyte populations. $J$. Immunol. 140:3352-3357.

12. Salmon, M., G. D. Kitas, and P. A. Bacon. 1989. Production of lymphokine mRNA by CD45R+ and CD45R- helper T cells from human peripheral blood and by human CD4+ T cell clones. J. Immunol. 143:907-912.

13. Ehlers, S., and K. A. Smith. 1991. Differentiation of T cell lymphokine gene expression: the in vitro acquisition of T cell memory. J. Exp. Med. 173:2536.

14. Snapper, C., and W. Paul. 1987. Interferon-gamma and B cell stimulatory factor-1 reciprocally regulate Ig isotype production. Science (Wash. DC). 236:944-947.

15. Snapper, C., F. Finkelman, and W. Paul. 1988. Regulation of IgG1 and IgE production by Interleukin 4. Immunol. Rev. 102:51-75.

16. Sanders, M. E., M. W. Makgoba, S. O. Sharrow, D. Stephany, T. A. Springer, H. A. Young, and S. Shaw. 1988. Human memory T lymphocytes express increased levels of three cell adhesion molecules (LFA-3, CD2, and LFA1) and three other molecules (UCHL1, CDw29, and Pgp-1) and have enhanced IFN- $\gamma$ production. J. Immunol. 140:1401-1407.

17. Kibler, R., M. J. Hicks, A. L. Wright, and L. M. Taussig. 1986. A comparative analysis of cord blood and adult lymphocytes: interleukin-2 and interferon production, natural killer cell activity, and lymphocyte populations. Diagn. Immunol. 4:201-208.

18. Van Damme, J., J. Van Beeumen, B. Decock, J. Van Snick, M. De Ley, and A. Billiau. 1988. Separation and comparison of two monokines with lymphocyte-activating factor activity: IL- $1 \beta$ and hybridoma growth factor (HGF): identification of leukocyte-derived HGF as IL-6. J. Immunol. 140:1534-1541.

19. Muraguchi, A., T. Hirano, B. Tang, T. Matsuda, Y. Horii, K. Nakajima, and T. Kishimoto. 1988. The Essential role of B cell stimulatory factor 2 (BSF-2/ IL-6) for the terminal differentiation of B cells. J. Exp. Med. 167:332-344.

20. Splawski, J. B., L. McAnally, and P. E. Lipsky. 1989. IL 2 dependence of the promotion of human B cell differentiation by IL 6 (BSF-2). J. Immunol. 144:562-569.

21. Boyum, A. 1968. Isolation of mononuclear cells and granulocytes from human blood: isolation of mononuclear cells by one centrifugation and sedimentation at 1 g. Scand. J. Clin. Lab. Invest. 21(Suppl. 97):77-89.

22. Hirano, T., T. Taga, N. Nakano, K. Yasukawa, S. Kashiwamura, K. Shimizu, K. Nakajima, K. H. Pyun, and T. Kishimoto. 1985. Purification to homogeneity and characterization of human B-cell differentiation factor (BCDF or BSFp-2). Proc. Natl. Acad. Sci. USA. 82:5490-5494.

23. Hirano, T., K. Yasukawa, H. Harada, T. Taga, Y. Watanabe, T. Matsuda, S. Kashiwamura, K. Kakajima, K. Koyama, A. Iwamatu, et al. 1986. Complementary DNA for a novel human interleukin (BSF-2) that induces B lymphocytes to produce immunoglobulin. Nature (Lond.). 324:73-76.

24. Hansen, J. A., P. J. Martin, P. G. Beatty, E. A. Clark, and J. A. Ledbetter 1984. Human T lymphocyte cell surface molecules defined by the workshop monoclonal antibodies ("T cell protocol"). In Leucocyte Typing. A. Bernard, L. Boumsell, J. Dausset, C. Milstein, and S. F. Schlossman, editors. Springer-Verlag, Inc., New York. 195-212.

25. Uchiyama, T., S. Broder, and T. A. Waldmann. 1981. A monoclonal antibody (anti-Tac) reactive with activated and functionally mature human $T$ cells. I. Production of anti-Tac monoclonal antibody and distribution of Tac (+) cells. J. Immunol. 126:1393-1397.

26. Morimoto, C., N. L. Letvin, J. A. Distaso, W. R. Aldrich, and S. F. Schlossman. 1985. The isolation and characterization of the human suppressor inducer T cell subset. J. Immunol. 134:1508-1515.

27. Thiele, D. L., M. Kurosaka, and P. E. Lipsky. 1983. Phenotype of the accessory cells necessary for mitogen-stimulated $T$ and $B$ cell responses in human peripheral blood: delineation by its sensitivity to the lysosomotrophic agent, $\mathrm{L}$ leucine methyl ester. J. Immunol. 131:2282-2290.

28. Thiele, D. L., and P. E. Lipsky. 1985. Modulation of human natural killer cell function by L-leucine methyl ester: Monocyte-dependent depletion from human peripheral blood mononuclear cells. $J$. Immunol. 134:786-793.

29. Galili, U., and M. Schlesinger. 1974. The formation of stable E rosettes 
after neuraminidase treatment of either human peripheral blood lymphocytes or of sheep red blood cells. J. Immunol. 112:1628-1634.

30. Jelinek, D. F., and P. E. Lipsky. 1985. The roles of T cell factors in activation, cell cycle progression, and differentiation of human B cells. $\mathrm{J}$. Immunol. 134:1690-1701.

31. Geppert, T. D., and P. E. Lipsky. 1987. Accessory cell independent proliferation of human $\mathrm{T} 4$ cells stimulated by immobilized monoclonal antibodies to CD3. J. Immunol. 138:1660-1666.

32. Jelinek, D. F., J. B. Splawski, and P. E. Lipsky. 1986. Human peripheral blood B lymphocyte subpopulations: Functional and phenotypic analysis of surface IgD positive and negative subsets. J. Immunol. 136:83-92.

33. Ferrante, A., B. Rowan-Kelly, L. J. Beard, and G. M. Maxwell. 1986. An enzyme-linked immunosorbant assay for the quantitation of human IgG subclasses using monoclonal antibodies. J. Immunol. Methods. 93:207-212.

34. Baroja, M. L., and J. L. Ceuppens. 1987. More exact quantitation of Interleukin 2 production by addition of anti-Tac monoclonal antibody to cultures of stimulated lymphocytes. J. Immunol. Methods. 98:267-270.

35. Defrance, T., J. Aubry, F. Rousset, B. Vanbervliet, J. Bonnefoy, N. Arai, Y. Takebe, T. Yokota, F. Lee, and K. Arai. 1987. Human recombinant interleukin 4 induces Fc epsilon receptors (CD23) on normal human B lymphocytes. $J$. Exp. Med. 165:1459-1467.

36. Prete, G., E. Maggi, P. Parronchi, I. Chretien, A. Tiri, D. Macchia, M. Ricci, J. Banchereau, J. De Vries, and S. Romagnani. 1988. IL-4 is an essential factor for the IgE synthesis induced in vitro by human $\mathrm{T}$ cell clones and their supernatants. J. Immunol. 140:4193-4198.

37. Jelinek, D. F. J. B. Splawski, and P. E. Lipsky. 1986. The roles of interleukin 2 and interferon- $\gamma$ in human B cell activation, growth and differentiation. Eur. J. Immunol. 16:925-932.

38. Kronke, M., W. J. Leonard, J. M. Depper, S. K. Ayra, F. Wong-Staal, R. C. Gallo, R. A. Waldmann, and W. C. Greene. 1984. Cyclosporin A inhibits T-cell growth factor gene expression at the level of mRNA transcription. Proc. Natl. Acad. Sci. USA. 81:5214-5218.

39. Clement, L. T., P. E. Vink, and G. Bradley. 1990. Novel Immunoregulatory functions of phenotypically distinct subpopulations of $\mathrm{CD} 4^{+}$cells in the human neonate. J. Immunol. 145:102-108.

40. Hirohata, S., D. F. Jelinek, and P. E. Lipsky. 1988. T cell-dependen activation of $\mathrm{B}$ cell proliferation and differentiation by immobilized monoclonal antibodies to CD3. J. Immunol. 140:3736-3744.

41. Amoroso, K., and P. E. Lipsky. 1990. Frequency of human B cells that differentiate in response to anti-CD3 activated T cells. J. Immunol. 145:31553161 .

42. Morell, A., F. Skvaril, W. H. Hitzig, and S. Barandun. 1972. IgG subclasses: development of the serum concentrations in "normal" infants and children. J. Pediatr. 80:960-964.

43. Oxelius, V. A. 1979. IgG subclass levels in infancy and childhood. Acta. Paediatr. Scand. 68:23-27.
44. Flanagan, J., and T. Rabbitts. 1982. Arrangement of human immunoglobulin heavy chain constant region genes implies evolutionary duplication of a segment containing $\gamma, \epsilon$, and $\alpha$ genes. Nature (Lond.). 300:709-713.

45. Coffman, R., J. Ohara, M. Bond, J. Carty, A. Zlotnik, and W. Paul. 1986. $B$ cell stimulatory factor- 1 enhances the IgE response of lipopolysaccharide-activated B cells. J. Immunol. 136:4538-4541.

46. Del Prete, G., E. Maggi, P. Parronchi, I. Chretien, A. Tiri, D. Macchia, M. Ricci, J. Banchereau, J. De Vries, and S. Romagnani. 1988. IL-4 is an essential factor for the IgE synthesis induced in vitro by human $T$ cell clones and their supernatants. J. Immunol. 140:4193-4198.

47. Hirohata, S., and P. E. Lipsky. 1989. T cell regulation of human B cell proliferation and differentiation: Regulatory influences of CD45R+ and CD45R - T4 cell subsets. J. Immunol. 142:2597-2607.

48. Hilbert, D. M., M. P. Cancro, P. A. Scherle, R. P. Nordan, J. Van Snick W. Gerhard, and S. Rudikoff. 1989. T cell derived IL-6 is differentially required for antigen-specific antibody secretion by primary and secondary B cells. $\mathrm{J}$. Immunol. 143:4019-4024.

49. Matsuzaki, N., F. Saji, T. Kameda, K. Yoshizaki, T. Okada, K. Sawai, and O. Tanizawa. 1990. In vitro and in vivo production of interleukin-6 by fetal mononuclear cells. Clin. Immunol. Immunopathol. 55:305-314.

50. Kasahara, Y., T. Miyawaki, K. Kato, H. Kanegane, A. Yachie, T. Yokoi, and N. Taniguchi. 1990. Role of interleukin 6 for differential responsiveness of naive and memory $\mathrm{CD} 4^{+} \mathrm{T}$ cells in $\mathrm{CD} 2$-mediated activation. $J$. Exp. Med. 172:1419-1424.

51. Smeland, E. B., H. K. Blomhoff, S. Funderud, M. R. Shalaby, and T Espevik. 1989. Interleukin 4 induces selective production of interleukin 6 from normal human B lymphocytes. J. Exp. Med. 170:1463-1468.

52. Renz, H., B. D. Mazer, and E. W. Gelfand. 1990. Differential inhibition of $T$ and $B$ cell function in IL-4-dependent IgE production by cyclosporin $A$ and methylprednisolone. J. Immunol. 145:3641-3646.

53. Sanders, V., R. Fernandez-Botran, J. Uhr, and E. Vitetta. 1987. Interleukin 4 enhances the ability of antigen-specific B cells to form conjugates with $T$ cells. J. Immunol. 139:2349-2354.

54. Gordon, J., M. Millsum, G. Guy, and J. Ledbetter. 1988. Resting B lymphocytes can be triggered directly through the CDw40 (Bp50) antigen: A comparison with IL-4-mediated signaling. J. Immunol. 140:1125-1430.

55. Ledbetter, J., F. M. Shu, M. Gallagher, and E. Clark. 1987. Augmentation of normal and malignant $B$ cell proliferation by monoclonal antibody to the B cell-specific antigen Bp50 (CDw40). J. Immunol. 138:788-794.

56. Jabara, H. H., S. M. Fu, R. S. Geha, and D. Vercelli. 1990. CD40 and IgE: Synergism between anti-CD40 monoclonal antibody and Interleukin 4 in the induction of IgE synthesis by highly purified human B cells. J. Exp. Med. 172:1861-1864.

57. Banchereau, J., P. De Paoli, A. Valle, E. Garcia, and F. Rousset. 1991. Long-term human B cell lines dependent on Interleukin-4 and antibody to CD40. Science (Wash. DC). 251:70-72. 